УДК 821.161 .2

DOI: $10.31558 / 2308-1902.2019 .27 .2$

Наталія ГОРОДНЮК

доктор філологічних наук, доцент, Маріупольський державний університет

\title{
ОБРАЗИ ПЕКЕЛЬНОЇ МАШИНИ ТА ЧАВУННОГО КОМАНДОРА У РОМАНІ ГОРДІЯ БРАСЮКА «ДОННА АННА»
}

У статті проаналізовано практично не досліджений роман представника Розстріляного Відродження Гордія Брасюка «Донна Анна» (1929) в аспекті семантики пекельної машини та через зіткнення двох світоглядів чоловіків-суперників - апологета індустрії, інженера-винахідника та служителя муз, композитора і музиканта. Зокрема, встановлено, що крім проблем статі, кохання, потягу, шлюбної моралі та зради, оприявлених у романі, виразно постає ще одна - зіткнення двох типів творчості, двох підходів до неї, уособлюваних героями-чоловіками, - людини діяльної, Homo faber, інженера Ніка Бачинського (залізного Командора) та людини мистецтва, театральної богеми, Homo ludens, композитора Володимира Шальвія (втілення музичної стихії та свободи пристрасті, Дон Жуана). Перший тип репрезентує авангардного героя - новітнього залізного бога, підкорювача енергії та земних надр (соціокультурний типаж пролеткульту та футуризму), другий - тип модерністського героя-митця, релятивіста та іммораліста. Головну роль у вирішенні такого світоглядного протистояння відіграє образ пекельної машини - винаходу, що знищує свого винахідника. Так, ретельна деталізація пекельної машини у дії - з численними звуковими, кольоровими та піротехнічними подробицями, а також експресивною реакцією глядачів та уявною смертю інженера - сюжетно передує i семантично пов'язана 3 епізодом-умовчанням - загибеллю винахідника під час випробування. Ця сцена машини у дії ніби передбачає долю новітнього Командора доби чавуну. Врешті життєвої поразки зазнає кожен із представників окресленого любовного трикутника: залізний Командор гине від власного винаходу, хай і за безпосередньої участі Дон Жуана, його винахід привласнено іншим, а його чавунна постать 3'являється німим докором лише колишній дружині і не в змозі покарати головного кривдника; скніє і волелюбний Дон Жуан, ніби розплачуючись за поєднання у власній особі генія та злочинства і повністю втрачаючи творчу наснагу після знищення Ганною його опери та аборту Талі; занепадає духом, змирившись із роллю куховарки, і Донна Анна.

Ключові слова: модернізм, роман, образ пекельної машини, Дон Жуан, Командор, Г. Брасюк

Постановка проблеми в загальному вигляді. Серед персоналій Розстріляного Відродження постать Гордія Брасюка (1899-1944) є найменш поцінованою, а його проза - найменш дослідженою на сьогоднішній день. Mema cmammi - проаналізувати роман письменника «Донна Анна» (1929) в аспекті ключових проблем модернізму.

Виклад основного матеріалу. Образ пекельної машини в поєднанні 3 мотивом генія та злодійства й інтертекстуальним обігруванням сюжетної 
канви протистояння Дон Жуана та Командора виразно окреслюється в романі Гордія Брасюка «Донна Анна», де любовний трикутник Ганна Бачинська (Донна Анна) - Нік Бачинський (Командор) - Володимир Шальвій (Дон Жуан) реалізовано через зіткнення двох світоглядів та двох позицій чоловіківсуперників - апологета індустрії, інженера-винахідника та служителя муз, композитора і музиканта. А крім проблем статі, кохання, потягу, шлюбної моралі та зради, оприявлених у романі, виразно постає ще одна - зіткнення двох типів творчості, двох підходів до неї, уособлюваних героями-чоловіками, людини діяльної, Homo faber, інженера Ніка Бачинського (залізного Командора) та людини мистецтва, театральної богеми, Homo ludens, композитора Володимира Шальвія (втілення музичної стихії та свободи пристрасті, Дон Жуана).

Перший тип репрезентує авангардного героя - новітнього залізного бога, підкорювача енергії та земних надр (соціокультурний типаж пролеткульту та футуризму), другий - тип модерністського героя-митця, релятивіста та іммораліста. Врешті, як засвідчує кінцівка твору, життєвої поразки зазнає кожен із представників окресленого любовного трикутника: залізний Командор гине від власного винаходу, хай і за безпосередньої участі Дон Жуана, його винахід привласнено іншим, а його чавунна постать 3’являється німим докором лише колишній дружині і не в змозі покарати головного кривдника; скніє і волелюбний Дон Жуан, ніби розплачуючись за поєднання у власній особі генія та злочинства і повністю втрачаючи творчу наснагу після знищення Ганною його опери та аборту Талі; занепадає духом, змирившись із роллю куховарки, і Донна Анна.

Амбівалентність машини в романі яскраво виявляється в епізоді демонстрації Бачинським винаходу власній дружині: 3 одного боку, побожне захоплення Ганни, з іншого - жах від некерованої дикої стихії, що загрожує вирватися: «Ганна в німому захопленні наблизилась до машини. Її очі були зачаровані мідною павутиною статору. <..> Нік підійшов до мотора, простяг руку до пускового реостату і ту ж мить, як з наказу чарівника, ворухнувся 
ротор, задвигтів поміст, залізна гора важко засопла, заревла... Здавалось, в залізний панцир Нік замкнув усі сили дикої стихії і от, тільки прийшов, вони прокинулись, потворно заревли на безліч голосів, погрожуючи розірвати панцир. В лабораторії стався до того нестерпний гул, що Ганна, захищаючи однією рукою вуха, другу простягла благально до Ніка. // Нік підняв руку й грізні потвори 3 незадоволеним завиванням покірливо вмовкли // Ганна побожно дивилася на Ніка. Він був той Прометей, що мав дати нову іскру людству. Його генератор - це була лише частка великого задуму. Він його здійснить безперечно. Ганна була певна в Ніковій силі» [1, с. 26].

Винахід Ніка - пристрій для бездротової передачі електричного струму має всі ознаки пекельної машини: її зблиски, полум’я, гудіння та рев незмінно викликають страх у більшості глядачів. Згадаймо епізод демонстрації винаходу на дні народження: «Раптом розлігся тріск, як випал якого десятка рушниць. Поміж опуками майнув вогнений язичок. За хвилину вже велике полум'я розцвічувалося дивовижними сліпучими кольорами. Фіалковий, помаранчовий, синій, червоний, зеленкуватий... Кольори мінилися, зливалися один $з$ одним, як світляна музика, що ілюструвала безугавну заглушливу какофонію тріску й гулу. Полум'я пливло по поверхні опук, досягало величезних загрозливих розмірів, розтягувалось між скрайніми точками опук, і згасало; та вслід вибухала нова сліпуча смуга. Ще момент і, здавалось, стіни лябораторії рухнуться від грому й полум'я. Але машина, ніби важко відсапуючись від утоми, поволі змовкла. Світло електрики обдало зблідлі обличчя жінок. В очах одсвічується одночасно переляк і захоплення. Хтось злякано віддихується, хтось захоплено жестикулює, хтось плеще в долоні. <...> За хвилину машина знову загула. Нік повернув підойму, увімкнув цілу серію якихось мечиків і став поміж двох мідних опук. Язики полум'я посунули по їх поверхні. Тоді Нік спокійно поклав долоні в полум’я зверху на опуки й той момент жах відбився в очах присутніх. Полум'я Нікові охопило все обличчя, здавалося, зараз спалахне йому волосся й він, обгорілий, бездушно гримнеться вбитий електричним струмом...» [1, с. 139]. Така ретельна деталізація 
пекельної машини в дії - 3 численними звуковими, кольоровими та піротехнічними подробицями, а також експресивною реакцією глядачів та уявною смертю інженера - сюжетно передує i семантично пов'язана 3 епізодом-умовчанням - загибеллю винахідника під час випробування. Ця сцена машини в дії ніби передбачає долю новітнього Командора доби чавуну. Так, демонструючи вже майже завершену машину Ганні після їхнього розлучення, Нік зауважує: «Мене мучить ця машина, над якою я десять років працював. Найкращих десять років нашого спільного життя. Тепер вона мені здається гільйотиною, на якій я мушу знищити себе» [1, с. 125-126].

Безпосередньо згадка про пекельну машину артикулюється в іншому епізоді: під час частування Ніка в помешканні колишньої дружини та іiі коханця останній кидає п’яну репліку: «А все ж люди в цілому такі підлі, що краще було б, коли б ви замість своєї електричної машини вигадали якусь пекельну. Тоді, напевне, я був би вашим спільником» [1, с. 150]. Ця репліка набуває звучання тривожної перестороги, ніби передбачення жорстокого задуму Володимира з усунення суперника, що увиразнюється у тексті музичним етюдом під назвою «Катастрофа» у виконанні підпилого композитора: «...I враз дике престо обірвало Ганні думки. 3-під пальців Володимира звуки здіймалися з такою експресією, ніби справді хтось раптом завів пекельну машину й розпочав свою руїнницьку працю. Ніби громово рушились кам'яні стіни, какофонічним брязком металю заглушувалися розпачливі зойки верхнього регістру. В тих зойках благальний немощний людський голос, що гине в руїні, але невблаганні вибухи, як ритми морських валів, насуваються один за одним і врешті... дев’ ятий. В ньому конденсується надсадливим фортісімо й грім, і брязк, і зойк... Все вмовкає під руїною каміння й заліза. Ще за інерцією зриваються десь поодинокі брили, ще якийсь залізний уламок з брязкотом котиться в прірву, щерхне щебень і тихо, як на страшному гробовищі» [1, с. 151]. Сама назва етюду, його тональність, какофонічний брязкіт, звуки грому та руйнування каменю і металу, людські зойки - все це звукове утілення пекельної машини, на яку перетворюється винахід Ніка, 
оскільки наступною фабульною подією твору, не артикульованою у сюжеті, а окресленою лише натяками, є загибель винахідника під час демонстрації власного винаходу. Відзначимо також двозначність репліки Володимира, сказаної після загибелі інженера: «Його вбито... Його вбила машина!» [1, с. 155].

3 образом машини нерозривно поєднано і постать самого винахідника, що постає ніби органічним продовженням свого дітища, утіленням стихії металу: у світоглядній позиції героя безпосередньо відбито філософськоестетичні положення пролеткульту та футуризму у потрактуванні технічних надможливостей людства та людини як робітника-титана, нового залізного бога, підкорювача природи. Згадаймо дискусію між чоловіками-суперниками про красу заходу сонця, обстоювану композитором, та велич індустріальних надпотужностей i рукотворних виробів людства, безапеляційно проголошувану інженером.

Чоловік Ганни інженер-винахідник Нік Бачинський має виразні риси новітнього Командора, який замість традиційної стихії каменю (камінна статуя, камінний гість, камінний господар) втілює твердість, вагу та застиглість металу, виступаючи залізним богом, повелителем сплавів та енергій. Така семантика металу незмінно постає у портретних характеристиках героя, поданих очима самої Ганни. Так, Бачинський «імпозантний, 3 твердим лицем мусянжового сплаву» [1, с. 8]; «слово «Нік» вона [Ганна - Н.Г.] сприймала ясним, як нікель» [1, с. 8]; «В йому здорова кров, здорова праця, залізні м’язи. Нік - метал. Крицева воля, срібний полиск душі» [1, с. 9].

Герой Брасюка знаходить надміцний сплав для свого винаходу, а його машина постає «залізною горою». Згадаймо, в Лесі Українки такою, лише камінною, горою з дівочих мрій Донни Анни виступає сам Командор, уособлюючи сталість, нерухомість і застиглість. Сам вигляд машини Ніка безпосередньо актуалізує таку семантику: «залізна гора, що нерухомо стала своєю основою на новий деревляний поміст» [1, с. 25].

В одному з епізодів Володимир називає суперника «чавунним казаном», а Ганна, пригнічена непоступливістю та невмолимістю чоловіка, подумки 
погоджується із цим визначенням: «Так, так. Нік - бездушний чавун. Вона забуде в йому навіть людську подобу. Чавун!» [1, с. 86]. Врешті пам’ятник на могилі загиблого від руки Дон Жуана Бачинського також чавунний. Семантика чавуну - цього надважкого металу - синонімічна символіці камінного у творі Лесі Українки: «Новий чавунний обеліск крицево мінився на сонці. Він міцно стояв на своєму постаменті. Здавалось - то горда Нікова постать» [1, с. 232]. Постать загиблого у візіях Ганни також з'являється у вигляді чавунного обеліска - семантичного еквівалента традиційної статуї: «Як грізний докір перед нею випливає Нікова постать. Ганна вже ладна впасти перед нею навколішки, благаючи змилування, але при найменшому русі вона знову притомніє. <..> Докірлива постать невідступно стоїть перед нею, то як чавунний грізний обеліск, то як мусянжове обличчя, що пильно вдивляється в неї страшними очима» [1, с. 265].

Водночас відзначимо, що «камінне» (у Лесі Українки) та «чавунне» (у творі Брасюка) виразно маркують різні культурні періоди: «камінь» - ранній модернізм, «чавун» - модернізм 1920-х років. Згадаймо знакові рядки П. Тичини із «Псалма залізу»: «Минув, як сон, блаженний час // і готики, й бароко. // Іде чугунний ренесанс, // байдуже мружить око».

Крім безпосередньої вказівки на оперу Моцарта «Дон Жуан», яку відвідує Ганна під час 3'ясування обставин загибелі свого чоловіка та ймовірної причетності до цього іiі коханця, сюжет якої, як, власне, і назва самого роману, постає кодом прочитання твору Брасюка, маємо низку речових підказок-повторів, розкиданих у тексті. Так, виразною алюзією на традиційне вбрання Командора - плащ - виступає довжелезне хутро Ніка Бачинського, у яке Ганна після смерті чоловіка змушує убратися Володимира. Це довгополе вбрання, у якому новий власник виглядає дещо неоковирно, набуває у романі лейтмотивного звучання: після з'ясування причетності Володимира до смерті чоловіка хутро ввижається Ганні у крові, але вже в кінці твору, змирившись із долею та зі своєю пасивною роллю у житті обох чоловіків, Ганна пересипає хутро нафталіном. 
Авангардна філософія техніки, віра в машину та технічний прогрес людства обігрується у Брасюка в образі винахідника Ніка Бачинського i репрезентується очима головної героїні роману - Донни Анни - Ганни Бачинської. Авторська іронія у цьому плані обумовлена ще й виразно підпорядкованою, залежною позицією героїні, переконання та життєва стратегія якої повністю визначається тим, поруч із яким чоловіком вона перебуває в цей момент: у шлюбі з Бачинським вона повністю розділяє його переконання, перейнявшись його вірою у технічні надможливості людства та визначальну роль у цьому винаході свого чоловіка («О, яка горда була Ганна 3 того, горда Ніком! В його самітності був великий світ майбутнього. Його лабораторія була повна моделів машин, повна проєктів. Він вірить, що гігантський кран піднесе чоловіка над його багном, дасть у руки міць і гордість. Машина переродить землю, машина очистить повітря, очистить людину, поширить обрії до найвищих здобутків, до найвищої моралі» [1, с. 10]; і далі: «Вона увірувала в Ніка, вона слугувала йому, як кумирові» $[1$, с. 10]), натомість покинувши Бачинського i зійшовшись iз Шальвієм, відновлює свої уроки співу та починає співати в опері.

Для Брасюка в цілому характерне модерністське потрактування техніки як загрози внутрішньому світу та існуванню людини, що виявляється не лише в інтерпретації винаходу Бачинського як пекельної машини, а й семантиці знакових для модерністських текстів образів - поїзда, трамвая та автобуса. Згадаймо численні катастрофічно-апокаліптичні образи різного рівня: від відрізаної трамваєм голови Берліоза у М. Булгакова до перебитого трамваєм хребта коня у поезії В. Сосюри, поїзда як пекельного дракона в I. Багряного та автобуса, що розчавлює дитину, у М.Хвильового. Гук паротяга в романі Брасюка- як знак загроженості для героїв, наростання тривожності в епізоді, коли Ганна остаточно переконалася у зраді Ніка, - символізує розпад усталених сімейних зв'язків, шлюбу (ця семантика стає традицією після виходу роману Л. Толстого «Анна Кареніна»), потенційно втілює приховану загрозу для кожного із членів цієї сім'ї, ніби передбачаючи численні нещастя, що в 
подальшому випадають на їхню долю: загибель Ніка, втрату ілюзій, невроз та беззмістовне рабське існування Ганни, адюльтер із вітчимом та аборт Талі.

Висновки. Отже, винайдений механізм у романі Брасюка виявляє всі ознаки пекельної машини, а інженер-винахідник постає новітнім Командором, який замість каменю утілює стихію чавуну, гинучи у протистоянні з людиною мистецтва - Дон Жуаном нового часу.

\section{ЛІТЕРАТУРА}

1. Брасюк Г. Донна Анна: роман. Київ : Сяйво, 1929. 300 с.

\section{REFERENCES}

1. Brasiuk, H. (1929). Donna Anna [Donna Anna]. Kyiv: Siajvo. [in Ukrainian].

\section{АННОТАЦИЯ \\ Наталья Городнюк. Образы адской машины и чугунного Командора в романе Гордея Брасюка «Донна Анна».}

В статье проанализирован практически не исследованный роман представителя Расстрелянного Возрождения Гордея Брасюка «Донна Анна» (1929) в аспекте семантики адской машины и столкновения двух мировоззрений мужчин-соперников - апологета индустрии, инженера-изобретателя и служителя муз, композитора и музыканта. В частности, установлено, что кроме проблем пола, любви, влечения, брачной морали и измены, воплощенных в романе, определенно возникает еще одна - столкновение двух типов творчества, двух подходов к нему, олицетворяемые героями-мужчинами, - человека деятельного, Homo faber, инженера Ника Бачинского (железного Командора) и человека искусства, театральной богемы, Homo ludens, композитора Владимира Шальвия (воплощение музыкальной стихии и свободы страсти, Дон Жуана). Первый тип представляет авангардного героя - нового железного бога, покорителя энергии и земных недр (социокультурный типаж пролеткульта и футуризма), второй - тип модернистского героя-художника, релятивиста и имморалиста. Главную роль в решении такого мировоззренческого противостояния играет образ адской машины - изобретения, уничтожающего своего изобретателя. Так, тщательная детализация адской машины в действии - c многочисленными звуковыми, цветовыми и пиротехническими подробностями, а также экспрессивной реакцией зрителей и мнимой смертью инженера сюжетно предшествует и семантически связана с эпизодом-умолчанием - гибелью изобретателя при испытании. Эта сцена машины в действии будто предопределяет судьбу нового Командора эпохи чугуна. В самом конце жизненное поражение настигает каждого из представителей очерченного любовного треугольника: железный Командор погибает от собственного изобретения, пусть и при непосредственном участии Дон Жуана, его изобретение присвоено другим, а его чугунная фигура появляется немым укором только бывшей жене и не в состоянии наказать главного обидчика; прозябает и свободолюбивый Дон Жуан, расплачиваясь за сочетание в собственной личности гения и злодейства и полностью теряя творческое вдохновение после уничтожения Анной его оперы и аборта Тали; падает духом, смирившись с ролью кухарки, и Донна Анна.

Ключевые слова: модернизм, роман, образ адской машины, Дон Жуан, Командор, Г. Брасюк. 


\section{ABSTRACT \\ Natalia Gorodnyuk. The Image of an Infernal Machine and the Character of Cast Iron Commander in the Novel "Donna Anna" by Hordiy Brasiuk}

«Donna Anna» (1929) by Hordiy Brasiuk (the representative of Executed Renaissance) is virtually unexamined novel. Therefore, in the article, the novel is analyzed in the aspect of the semantics of the infernal machine and through the conflict between two outlooks of male opponents - the apologist of the industry, the engineer-inventor and the servant of Muses, the composer and the musician. It has been defined that besides the problems of sex, love, desire, marital morality and betrayal presented in the novel, one more clearly stands out - the collision of two types of creativity, two approaches to it. These types are embodied by male heroes - man of action, Homo faber, engineer Nick Bachinsky (Cast Iron Commander) on the one hand and man of art and theatrical bohemian, Homo ludens, composer Volodymyr Shalvia (embodiment of musical element and freedom of passion, Don Juan) from another. The first type represents the avant-garde hero - the newest iron god, the conqueror of energy and the earth's interior (the sociocultural type of proletkult and futurism). The second is a type of modernist hero-artist, relativist, and immoralist. And the image of the infernal machine - the invention that destroys its inventor plays a leading part in solving such an ideological confrontation. Thus, numerous sound, color and pyrotechnical details in the description of the infernal machine in action, as well as the expressive reaction of the viewers and the imaginary death of the engineer are preceded by a plot and are semantically related to the episode of default - the death of the inventor during the experiment. This scene of machine in action seems to suggest the fate of the newest Commander in the epoch of iron cast. In the end, life defeat is experienced by each of the representatives of the outlined love triangle. The Cast Iron Commander perished by his own invention (even if it happened with direct participation of Don Juan), his invention is seized to others, and his cast-iron figure arises like mute reproach only to his former wife, and he is unable to punish the main abuser. Freedomloving Don Juan becomes a mere vegetable as if paying for the combination of genius and crime in his own person. And soon he completely loses his creative inspiration after that, as Anna destroyed his opera, and Talya made an abortion. Donna Anna is crestfallen, reconciling to the role of the cook.

Key words: modernism, novel, image of infernal machine, Don Juan, Commander, Brasiuk.

Стаття надійшла до редакиійної колегї 15.03.2019 p. Рекомендовано до друку 17.04.2019 р. 